DOI: $\square$ https://doi.org/10.15407/techned2020.05.019

\title{
FEATURES OF CONSTRUCTION OF BI - DIRECTIONAL CHARGING CONVERTERS FOR REALIZATION OF THE CONCEPT OF BILATERAL ENERGY-EXCHANGE "VEHICLE-TO-GRID" IN DISTRIBUTION NETWORKS
}

Journal

Publisher

ISSN

Issue

Pages
Tekhnichna elektrodynamika

Institute of Electrodynamics National Academy of Science of Ukraine 1607-7970 (print), 2218-1903 (online)

No 5, 2020 (September/October)

$19-25$

\section{Authors}
A.F. Zharkin ${ }^{1 *}$, V.O. Novskiy ${ }^{1 * \star}$, O.P. Zapadynchuk ${ }^{2}$, V.V. Martinov ${ }^{1 \star \star *}$
1 - Institute of Electrodynamic National Academy of Sciences of Ukraine,
Peremohy, 56, Kyiv, 03057. Ukraine,
e-mail: novsky@ied.org.ua
2 - Section of applied problems National Academy of Sciences of Ukraine,
Vladimirskaya St., 54, Kyiv, 01030, Ukraine
* ORCID ID : https://orcid.org/0000-0001-5996-0901
** ORCID ID : https://orcid.org/0000-0003-3857-7027
*** ORCID ID : https://orcid.org/0000-0003-2184-0394

\begin{abstract}
Aspects of the practical implementation of Vehicle-to-grid (V2G) technology for bi-directional energy exchange when connecting electric vehicles to a public electric network based on the use of the designed powerful bi-directional charging converter are considered. It is intended to the transmission of electric power from the distribution network to traction batteries of electric vehicles or hybrids for their charging and vice versa - from batteries to public electric network in order to smooth out the daily load schedule. The main technical solutions and features of the practical implementation of designed semiconductor converter that can use as part of powerful charging stations of electric vehicles and hybrids are presented. References 9 , figures 3 , table 1 .
\end{abstract}


Key words: electric car, traction battery, charging station, bi-directional converter, electrical network.

Received: 28.02.2020

Accepted: 21.04 .2020

Published: 25.08.2020

\section{References}

1. HEvCars. URL: https://hevcars.com.ua/glava-ukrenergo-elektromobili-pozitivno-vliyayut-naenergosistemu/16.11.2018 (accessed: 15.01.2020). (Rus)

2. Tesla Supercharger. URL: https://uk.wikipedia.org/wiki/Tesla_Supercharger (accessed:

22.12.2019). (Ukr)

3. Electric vehicles will help the shift toward EU's green transport future. 10 December 2019.

European Environment Agency. URL: https://www.eea.europa.eu/highlights/electric-vehicles-w ill-help-the/download.pdf . (accessed: 15.01.2020).

4. European Environment Agency. Electric vehicles from life cycle and circular economy perspectives. Transport and Environment Reporting Mechanism (TERM). Report EAA, 2018. 74 p. URL: https://www.eea.europa.eu/publications/electric-vehicles-from-life-cycle (accessed: 15.01.2020).

5. Nissan and Enel launch groundbreaking Vehicle-to-grid project in UK. Nissan News. 2016. (Rus)

URL: https://russia.nissannews.com/ru-RU/releases/release-145211-nissan-enel-vehicle-to-gri d (accessed: 25.01.2020).

$\overline{6}$. K.Uddin, T. Jackson, D.Widanage, G. Chouchelamane, P. Jennings, J. Marco. On the possibility of extending the lifetime of lithium-ion batteries through optimal V2G facilitated by an integrated vehicle and smart-grid system. Energy. August, 2017. DOI: https://doi.org/10.1016/j. Energy.2017.04.116+ tps://doi.org/10.1016/j.energy.2017.04.116

7. Beshta A.S., Aziukovski A.A., Khudolii E.P., Khudolii S.S., Balakhontsev O.V. Technical and economic justification of cogeneration technology with the use of electromobile. Elektrotehnika ta elektroenergetyka

. 2019. No 3. Pp. 42-51. (Ukr).

DOI:

https://doi.org/10.15588/1607-6761-2019-3-5

8. Hao Qian. A high-efficiency grid-tie battery energy storage system. Dissertation submitted to the faculty of the Virginia Polytechnic Institute of PhD diss.: Electrical Engineering. Blacksburg, Virginia. 2011. $150 \mathrm{p}$.

9. Zharkin A., Novskyi V., Martynov V. Powerful Unified Inverter Modules for Energy Storage 
Systems. IEEE 6th International Conference on ENERGY SMART SYSTEMS (IEEE ESS). 2019. Pp. 144-149.

DOI:

https://doi.org/10.1109/ESS.2019.8764177

PDF

(어요

This work is licensed under a Creative Commons Attribution-NonCommercial-NoDerivatives $\underline{4.0 \text { International License }}$ 